\title{
AN INVESTIGATION INTO POVERTY REDUCTION THROUGH FISHERIES ACTIVITIES
}

Note: Abridged version of the paper presented at the IIFET 2012 Tanzania: Conference on "Visible Possibilities: The Economics of Sustainable Fisheries, Aquaculture and Seafood Trade", to be held at Dar es Salaam, Tanzania, during July 16-20, 2012.

Authored by: Dr. Santosh Kumar Mishra (Ph. D.), Technical Assistant, Population Education Resource Centre (PERC), Department of Continuing and Adult Education and Extension Work, S. N. D. T. Women's University, Patkar Hall Building, First Floor, Room. No.: 03, New Marine Lines, Mumbai - 400020, Maharashtra, India, Tel.: 9102222066892 (O), 09224380445 (M), 9102228090363 (R), Email: drskmishrain@yahoo.com, Web Link: http://sndt. ac.in/

\section{INTRODUCTORY REMARKS:}

From the earliest times and in practically all countries, fisheries have been of industrial and commercial importance. Fisheries and aquaculture contribute significantly to food security. Livelihoods of millions of people across the regions of the globe depend on healthy aquatic ecosystems. Achieving the Millennium Development Goals to eliminate extreme poverty by 2015 requires a concerted and unified effort by governments and the international community (United Nations, 2010). Many fishers are poor and so targeting development interventions at fishing communities can help reduce poverty. In order to increase the contribution that fisheries make to poverty reduction, management that ensures sustainability of fish stocks and equitable distribution of the benefits is needed. To achieve this, policy-makers must recognize the important contributions that fisheries make at both national and local levels (FAO, 1999). This paper aims to examine how fisheries can contribute to poverty reduction, with relevant examples.

\section{THE ISSUE OF POVERTY:}

Poverty (defined as "the state of one who lacks a certain relative amount of material possessions or money") is a complex phenomenon involving failure to meet a range of basic human needs and the denial of options that have consequences for opportunities to live long, healthy and creative lives. Poverty in fishery dependent communities, therefore, is not solely related to the abundance of the catch, market opportunities or the state of the resource. It is also critically dependent on how the benefits from the use of fishery and other resources are used and whether a range of basic services (e.g. in health and education) are provided (FAO of the UN, 2005).

\section{FISHERIES DEVELOPMENT:}

Fisheries development is the process towards achieving the full potential of the sector through growth and improvement. A fishery is being developed if the biomass of the stock is being reduced by fishing, rebuilt (after depletion) or enhanced to increase its productivity. It is also developed if the quality of the catch or its value improves, not necessarily increasing the harvest. The main goal of an ecologically sustainable development is to improve the well-being of all the people engaged directly or indirectly in the fisheries sector, as well as the natural productive system. Under an ecosystem approach to fisheries, 'development' may be achieved by reducing the negative environmental impact and/or increasing resilience of the system to unexpected change, meeting broader societal objectives. As the full potential of wild fisheries resources has been achieved - and often 'lost' through 'overfishing' - the main objective and emphasis in capture fisheries development strategies has changed from increasing harvest (the main objective for three quarters of the last century) to establishing a more sustainable and optimal use of the available fisheries resources (particularly since UNCED in 1992). Concern for environmental management and sustainability appeared essentially during the 1990s (Abbot and Guijt, 1998).

\section{ECONOMIC DEVELOPMENT AND FISHERIES:}

The fisheries sector is rarely a strategic sector for national economic development. Although it plays a prominent role in only a few countries such as Iceland, Namibia, the Maldives and other small island developing states rich in fishery resources relative to their populations, it is nonetheless an important economic activity, and very often a strategic 
one, in many coastal regions of the world. Indeed, in many countries, fish export is a major contributor to foreign exchange earnings, often ranking far higher than other agricultural commodities. The major trade flow underlines the significance of this sector for the trade balance of many developing countries. Licensing fees of foreign fishing fleets are another source of foreign exchange revenue from marine fishery resources, especially in West African and South Pacific countries. The more considerable and substantial contribution of fisheries worldwide is the supply of highly nutritious animal protein for human consumption and the employment and income generation in often-remote coastal areas (Centre for Science and Environment, 1985).

\section{THE CONTRIBUTION OF FISHERIES TO POVERTY REDUCTION:}

\subsection{Fisheries are economically important:}

Fisheries provide an important source of revenue for many developing countries. Net fisheries exports amounted to US $\$ 17.4$ billion in 2002 in foreign exchange earnings for developing countries, more than the net exports of coffee, cocoa, sugar and tea combined.

\subsection{Fisheries are important to food security:}

Fisheries provide a key source of protein, micronutrients, essential fatty acids and minerals. They contribute to food security by providing an accessible and cheap protein source for the poor that complements other locally available food sources. Over one billion people worldwide rely on fish as their main source of animal protein. Fish are a particularly important source of protein in developing countries where protein intake may be low. For 2.6 billion people in developing countries, fish provides over $20 \%$ of total animal protein intake, compared with $8 \%$ in developed countries.

\subsection{Fisheries form a key part of livelihoods:}

Fisheries are an important part of the livelihoods of millions of people around the world. They provide a source of food, employment and income. For many poor families, fishing is a way of reducing their vulnerability to risks by supplementing and diversifying their incomes. They also provide a 'safety net' for the poor when other economic opportunities or food sources are limited (Binswanger and von Braun, 1993).

\section{CONTRIBUTION OF SMALL-SCALE FISHERIES TO ECONOMIC GROWTH AND POVERTY ALLEVIATION:}

The small-scale fisheries sector is generally described as being dynamic and evolving and is typically labour intensive, using relatively small amounts of capital and energy (OECD, 1972). Smallscale fishers use small vessels and often fish inshore for local and domestic markets although export-oriented production has increased significantly during the last couple of decades. The small-scale fisheries contribute to economic growth and poverty reduction by the following ways:

\subsection{Foreign exchange:}

Small-scale fisheries can make significant contributions to national economies through the generation of foreign exchange derived from international trade.

\subsection{Multiplier/GDP effects:}

Income multiplier effects can potentially "trickle up" to the national economy ensuring that small-scale fisheries can support national economic growth through contributions to gross domestic product (GDP).

\subsection{Tax generation:}

Taxes provide national governments with an opportunity to assist both poverty reduction and poverty prevention initiatives. Taxes made available to national treasuries can be spent on re-distributive mechanisms aimed at targeted poverty prevention or on generic social support.

\section{CONTRIBUTION OF SMALL-SCALE FISHERIES TO LOCAL ECONOMIES:}

Wealth generated by individuals, households or small enterprises can make significant contributions to local economies through income and employment multiplier effects. This is especially the case in fisheries because of the "cash crop" nature of the harvest. Fish may be one of the few products in some rural economies that can generate cash to spur and stimulate demand, because other food products may be more generally bartered or consumed within the household (Twopeny, 1983). 


\section{ENHANCING THE CONTRIBUTION OF FISHERIES TO POVERTY REDUCTION:}

Fisheries contribute to poverty reduction in the following ways:

- Effective management for sustainability,

- Coherent policy objectives,

- Governance and capacity building and

- Distribution of benefits.

\section{CONCLUDING REMARKS:}

Achieving the Millennium Development Goals to eliminate extreme poverty by 2015 requires a concerted and unified effort by governments and the international community. When fisheries are well managed, they can contribute to reducing poverty. The paper concludes that although much progress has been made towards understanding the contributions that fisheries can make to poverty reduction, and to achieving the Millennium Development Goals, further support is needed in the areas of: (a) strategies to maximize the benefits derived from fisheries and reduce the poverty and vulnerability of fishers; (b) establishing appropriate governance structures and strengthening fisheries institutions dealing with management, especially in their ability to manage fisheries sustainably; and (c) raising awareness of the importance and contribution of fisheries to poverty reduction.

Keywords: fisheries, poverty reduction, development interventions, future work priorities, Millennium Development Goals

\section{REFERENCES:}

United Nations (2010): Making Millennium Development Goals Happen. New York, United Nations.

FAO (1999): Indicators for Sustainable Development of Marine Capture Fisheries. Rome, FAO.

FAO of the UN (2005): Increasing the Contribution of Small-Scale Fisheries to Poverty Alleviation and Food Security. FAO Technical Guidelines for Responsible Fisheries 10. Rome, FAO of the UN.

Abbot, J., Guijt, I. (1998): Changing Views on Change: Participatory Approaches to Monitoring the Environment, SARL Discussion, Paper No. 2. London: IIED.

Centre for Science and Environment (1985): The State of India's Environment 1984-85. New Delhi, Centre for Science and Environment.

Binswanger, H.P., von Braun, J. (1993): Technological Change and Commercialization in Agriculture. Washington DC, World Bank/IFPRI.

OECD (1972): Guiding Principles Concerning InternationalEconomicAspects of Environmental Policies. Council Recommendation C, 72, 128. Paris: OECD.

Richard Twopeny (1983): Town Life in Australia. London: Elliot Stock. 